\title{
Merinos - a profitable diversification option for most North island hill country
}

D.F. Wright', A.P. Rhodes* and G.J. Hamilton'

'Flock House Agricultural Centre, MAFTech, Bulls

${ }^{2}$ MAFTech, Dannevirke

'Wanganui Hill Research Area,

MAFTech, Wanganui

ABSTRACT Fine wool production is a small but increasingly important industry in New Zealand. To minimise the effects of fluctuations in world fine wool supply and demand, New Zealand must concentrate on quality. Results of a comparison with Romney ewes and lambs on hard hills at the Wanganui Hill Research Area, show that Merinos have performed well. Although flystrike and a lower tolerance to internal parasites were observed, predicted feet and wool quality problems did not eventuate. Any special management required has been more than compensated for by the $48 \%$ higher gross margins achieved in $1988-89(\$ 25.90$ per stock unit or $\$ 337 /$ ha from Merinos). Throughout the 1980 s, even when SMPs supported high lamb prices, Merinos would have been a better proposition than prime lamb. All farmers, especially those changing to Merinos, need to concentrate more on wool quality and quantity rather than lambing percentages and lamb weights. A Merino enterprise can be entered in two ways. Buying Merinos has a high initial cost, but the financial benefits are immediate and can be budgeted with more confidence using recent prices. Using Merino rams over crossbred ewes is a low cost alternative which is much slower $(15$ years), but the financial gains, although present from year 1 , are much reduced, particularly in the early years. In North Island hill country where inputs are low, Merinos are proving to be a profitable diversification option. The increase in disposable farm surplus of $\$ 33,100$ in the $1989 / 90$ year from a 3200 sheep stock unit hill country farm, has been much needed by farmers in recent years, and may have saved some from having to leave farming.

Keywords Merinos, hill country, wool, diversification

\section{INTRODUCTION}

In the early 1980s the emphasis for the North Island hill country farmer was on lamb production, as it had been for a century. At that time, however, New Zealand clearly could no longer afford to sustain subsidies on lamb or other agricultural commodities. The hill country farmer, who is much more constrained than his colleagues on flatter land, urgently required diversification options for his very survival, let alone his economic well-being.
Deer and goats were, and still are, two of these options but as history has shown, such new industries are particularly prone to livestock price speculation, resulting in some participants suffering financially, and the industry developing a bad reputation. Recovery from such setbacks is slow. Pine wool, however, has been a well established industry both internationally and in New Zealand, and although product and livestock prices are subject to fluctuations these are usually less.

MAFTech decided to evaluate Merinos as a diversification option for hill country farmers. In 1985, mature Merino wethers were introduced to sheep farmlets at the Wanganui Hill Research Area to compare with Romney ewes and lambs. From the outset, strong farmer interest was expressed in the economic performance of the Merinos and in whether they would thrive and produce, or indeed even survive in their new environment. The most common opinion expressed, both from traditional Merino farming areas of the South Island and from North Island farmers, was that any Merinos that appeared to adapt to the greener North Island pastures would ultimately succumb in large numbers to footrot and fleece rot. At the very least, fleece quality would be severely impaired. We were, however, encouraged by the earlier work at Tokanui Research Station (Dobbie et al. 1985).

A comprehensive Merino research programme is investigating the possibility of further enhancing profits from Merinos in the North Island through genetic improvement, reproduction, management and superfine wool production. Only the initial evaluation is reported here.

\section{FINE WOOL INDUSTRY}

The worlds fibre market is dominated by cotton and man-made fibres. The 3 million tonnes of greasy wool produced in $1987 / 88$ comprised only $5 \%$ of the fibre market (Statistical Handbook, 1987-88).

Merino wool (24 microns and finer) represented $46 \%$ by weight and $70 \%$ by value of all wool produced. New Zealand produces only $1 \%$ of the worlds Merino wool, the majority of which is grown in Australia and the Soviet Union. Recent increases in production in Australia are affecting prices. New Zealand must concentrate on producing high quality wool to minimise the extent of price decreases. The quality characteristics aimed for would include soundness, whiteness, low vegetable matter content, and perhaps fineness. Although New Zealand is 
predominantly a crossbred wool producer, the proportion of wool of 24 micron and finer has increased from $2.5 \%$ in $1984-85$ to $3.5 \%$ in $1987-88$. Only $0.6 \%$ of the 6500 clean tonnes of this wool was sold in the North Island, but this percentage is growing fast. Provided adequate access is given to good genetic material, the North Island with generally better nutritional control, should be able to produce sound wool with a very low vegetable matter content.

\section{PRODUCTION}

\section{Methods and Results}

Since there were no consistent differences between stocking rates, means of higher and medium stocking rate data are given in Table 1.

Table 1 Performance of mixed-age Romuey ewes and lambs, and mixed-age Merino wethers during 1986-88.

\begin{tabular}{|c|c|c|c|c|}
\hline & & 1986 & 1987 & 1988 \\
\hline No. adults & $\begin{array}{l}\text { Romney } \\
\text { Merino }\end{array}$ & $\begin{array}{c}78 \\
74\end{array}$ & $\begin{array}{l}78 \\
74\end{array}$ & $\begin{array}{l}78 \\
74\end{array}$ \\
\hline Adults/ha & $\begin{array}{l}\text { Romney } \\
\text { Merino }\end{array}$ & $\begin{array}{r}13 \\
18.5\end{array}$ & $\begin{aligned} 13 \\
18.5\end{aligned}$ & $\underset{18.5}{\mathbf{1 3}}$ \\
\hline $\begin{array}{l}\text { Deaths (Romneys replaced at } 5 \text { years) } \\
\text { (Merinos, only deaths replaced) }\end{array}$ & $\begin{array}{l}\text { Romney } \\
\text { Merino }\end{array}$ & $\begin{array}{l}3 \\
4\end{array}$ & $\begin{array}{c}3 \\
14\end{array}$ & $\begin{array}{r}5 \\
12\end{array}$ \\
\hline February liveweight (kg) & $\begin{array}{l}\text { Romney } \\
\text { Merino }\end{array}$ & $\begin{array}{l}42.0 \\
48.7\end{array}$ & $\begin{array}{l}43.8 \\
49.9\end{array}$ & $\begin{array}{l}45.1 \\
53.3\end{array}$ \\
\hline $\begin{array}{l}\text { Clean Fleece wt./adult } \\
\text { (kg of fleece }+ \text { bellies }+ \text { pieces })\end{array}$ & $\begin{array}{l}\text { Romney } \\
\text { Merino }\end{array}$ & $\begin{array}{l}2.8 \\
2.9\end{array}$ & $\begin{array}{l}3.0 \\
3.5\end{array}$ & $\begin{array}{l}2.9 \\
3.1\end{array}$ \\
\hline Mean fibre diameter (mircons) & $\begin{array}{l}\text { Romney } \\
\text { Merino }\end{array}$ & N $\underset{20.9}{\mathrm{~A}}$ & $\begin{array}{l}35.7 \\
21.0\end{array}$ & $\begin{array}{l}\text { NA } \\
21.1\end{array}$ \\
\hline Lamb liveweight-December (kg) & Romney & 18.0 & 21.2 & 19.4 \\
\hline Lamb sales - December ( $\mathbf{\$} / \mathbf{h a})$ & Romney & 117 & no & 132 \\
\hline Wool sales (\$/ha) & $\begin{array}{l}\text { Romney } \\
\text { Merino }\end{array}$ & $\begin{array}{c}194 \\
4 \mathrm{X}-\mathrm{I}\end{array}$ & $\begin{array}{l}226 \\
804\end{array}$ & $\begin{array}{r}247 \\
954\end{array}$ \\
\hline $\begin{array}{l}\text { Total income sheep and wool } \\
\text { sales minus sheep purchases ( } \mathbf{S} / \mathrm{ha})\end{array}$ & $\begin{array}{l}\text { Romney } \\
\text { Merino }\end{array}$ & $\begin{array}{l}251 \\
406\end{array}$ & $\stackrel{276}{707}$ & 331 \\
\hline
\end{tabular}

10 months' wool growth only

NA - not available

Each of the four farmlets (Merinos and Romneys at high and medium stocking rates) comprised 3 steep 1-ha paddocks of mainly sandstone soils - one each of a uniformly contoured sunny aspect, a more broken contoured shady aspect, and an intermediate aspect.

Sheep were set stocked for most of the year but during periods of actual or anticipated feed shortage (e.g. premating and during winter) the treatment groups were rotated in mobs around the replicate paddocks, using electric subdivision fences as necessary.

Rising B-year-old Romney ewes were replaced at weaning by rising 2-year-olds. Also, any ewes dying on the trial were replaced. Merino wethers dying on the trial were replaced by rising 2-year-olds.

Lambs were removed at weaning in December after being weighed and given a commercial value.

Flystrike was a major consideration with 8 and 6 Merino wethers and 1 and 3 Romney ewe and lambs struck in 1986 and 1987 respectively. This resulted in 2 and 4 Merino and 2 and 0 Romney deaths respectively. In 1988 with a different chemical programme, strike was absent.

Lice infestation was particularly noticeable in 1987 on the Merinos. Wool quality and susceptibility to flystrike appeared to be the main consequences.

On the basis of egg counts and disease diagnosis, Merinos were more susceptible than Romneys to challenge from internal parasites. As a result Merinos were drenched 8, 6 and 4 times in 1986, 1987 and 1988. This compares with 3, 3 and 3 for Romney ewes.

\section{DISCUSSION}

To allow for the effects of more intensive grazing management and in order not to buffer differences between the breeds, stocking rates were used which were higher than the district average for this class of land.

Accordingly, Romney ewe liveweights and per head fleece weights were lighter than the district average. Merino deaths were high after the first year probably because of the age of some of the wethers (some of 10 years and older) and the policy of replacement only on death.

Merino wool income per hectare was approximately 3.5 times that of the Romneys. Romney lamb and cull ewe sales were insufficient to make up that difference. Merino returns, being reliant on wool alone, must be considered a higher risk than a crossbred ewe-based system where wool and meat are produced.

Flystrike and internal and external parasites have been greater animal health problems with Merinos. These problems can be minimised by strategic management. Footrot, fleece rot and discoloration have proven of little significance in this flock. Wool yellowness, as indicated by Y-Z values of -1.5 to +3 , has been minimal and had little effect on price.

Merinos tend to graze in mobs usually near the tops of hills. They appear to have more of a browsing habit with a lower preference for legumes than do Romneys and do not select as strongly away from weeds.

Electric and traditional fences have been respected by Merinos although 5 were killed by them over the 3 years. When mustering and yarding they should be subjected to less dog pressure than Romneys. They can move freely over large distances in hill country.

\section{ECONOMICS}

\section{Method and Results}

Using production data from Table 1, farm cash surpluses have beén predicted for $1989 / 90$ of a model Wanganui hard hill country farm running Romney ewes or Merino wethers (Table 2).

The farm cash surplus is the difference between farm income and farm operating expenditure, including 
purchase of replacement stock, animal health, labour, fertiliser, repairs and maintenance, vehicle and administration expenses. The farm cash surplus is available for personal drawings, debt servicing, taxation, and other discretionary items.

Table 2 Predicted Economic Performance in $1989 / 90$ of a model Wanganui hard hill country farm running Romney ewes or Merino wethers.

\begin{tabular}{lcc}
\hline & $\begin{array}{c}\text { Romney } \\
\text { ewes }\end{array}$ & $\begin{array}{l}\text { Merino } \\
\text { wethers }\end{array}$ \\
\hline Wool kg/ssu (greasy) & 4.20 & 6.60 \\
Wool \$/kg (greasy) & 4.20 & 7.50 \\
Famb sale value (\$/lamb) & 11.50 & \\
2Farm Cash Surplus (\$) & 36300 & 69400 \\
Adjusted Farm Cash Surplus (\$) & 36300 & 40700 \\
\hline
\end{tabular}

'Unadjusted and

adjusted for additional capital invested in Merinos

The physical and financial parameters for this 3200 sheep stock unit farm are taken from MAFTech's Farm Monitoring Report (MAFTech, June 1989). The property also carries 900 cattle stock units. Farm cash surpluses have been calculated using 1989/90 product price assumptions. The fine wool price has been assessed at 1.8 times the crossbred wool prices (NZ Wool Board 1989). Farm cash surpluses are given with and without an interest payment (at 15\%) for the additional capital costs of purchasing Merinos.

Extra variable costs of $90 \mathrm{c} / \mathrm{sheep}$ stock unit have been included for Merinos. These are for extra dipping and drenching, but reduced for shearing associated with once yearly shearing.

Product prices have fluctuated annually, and have an effect on the relative returns from both the Romney ewe and Merino wether systems described. The effect of product returns on the two systems in the period $1981 / 82$ through to 198811989 has been assessed (Table 3).

The gross margins, calculated per stock unit, enable an economic comparison between enterprises with

Table 3 Comparative gross margins (\$/stock unit) of Romney ewes and Merino wethers on a typical Wanganui hard hill country farm over the period 1981/82 - 1988/89. (Based on Table 1 production data and published product returns _ NZMWBES 1981-88).

\begin{tabular}{lccc}
\hline & $\begin{array}{c}\text { Clean wool } \\
\text { price ratio } \\
(21 \mu \mathrm{m} / \mathbf{3 7} \boldsymbol{\mu m})\end{array}$ & Gomney ewes & Merino wetbers \\
\hline $\mathbf{1 9 8 1 / 8 2}$ & 1.87 & 10.50 & 16.50 \\
$\mathbf{1 9 8 2 / 8 3}$ & 1.98 & 10.60 & 17.90 \\
$\mathbf{1 9 8 3 / 8 4}$ & 1.93 & 14.30 & 21.90 \\
$\mathbf{1 9 8 4 / 8 5}$ & 2.48 & 17.70 & 42.50 \\
$\mathbf{1 9 8 5 / 8 6}$ & 1.77 & 12.10 & 22.10 \\
$\mathbf{1 9 8 6 1 8 7}$ & 1.66 & 17.00 & 21.50 \\
$\mathbf{1 9 8 7 / 8 8}$ & 2.30 & 17.40 & 33.20 \\
$\mathbf{1 9 8 8 / 8 9}$ & 2.40 & 17.40 & 25.90 \\
Mean & 2.05 & 14.60 & 25.20 \\
\hline
\end{tabular}

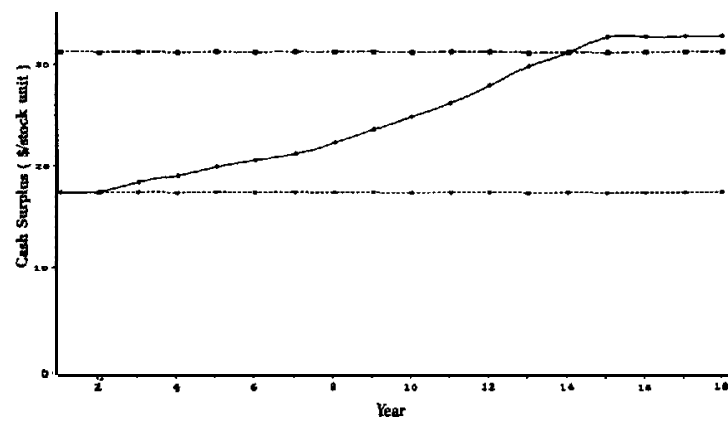

Figure 1 Cashflows for three sheep options for a typical Wanganui hard hill country farm.

c------c Continue with Romney (or other crossbred) flock

- Use Merino rams to breed Romney flock up to purebred Merino flock after $\mathbf{1 5}$ years.

\#...... Purchase Merino flock.

comparable overheads. Only variable costs associated with each enterprise are included.

Table 3 is based on the production data of Table 1 and published product returns (NZ Meat and Wool Board Economic Service, 1981-1988).

Breeding up to a Merino flock by mating existing crossbred ewes to Merino rams is an alternative which has some appeal, especially when the capital cost of purchasing Merinos is high, as at present. The entry costs of breeding up are lower but the financial benefits are slower in coming (Figure 1). Long term wool price ratios are used in these comparisons, and the opportunity cost of capital has been included at $15 \%$.

Table 4 Net present value of 15-year cashflow in Figure $1(10 \%$ discount rate).

\begin{tabular}{lc}
\hline & $\begin{array}{c}\text { Net present value } \\
(\$ / \text { stock unit) }\end{array}$ \\
\hline Romney flock & 141 \\
Cross breeding to Merino & 181 \\
Purchasing Merino & 260 \\
\hline
\end{tabular}

Table 5 Effect of three termination times on NPV (\$/stock unit) of cashflow in Figure 1 (10\% discount rate).

\begin{tabular}{lccc}
\hline & \multicolumn{3}{c}{ Termination } \\
& Year 5 & Year 10 & Year 15 \\
\hline Romney flock & 70 & 114 & 141 \\
Crossbreeding to Merino & 80 & 137 & 181 \\
Purchasing Merino & 130 & 210 & 260 \\
\hline
\end{tabular}

Table 6 Return on livestock expenditure $\boldsymbol{\sim}$ internal rate of return.

$\begin{array}{ll}\text { Romney Flock } & 91 \% \\ \text { Cross breeding to Merinos } & 93 \% \\ \text { Purchasing Merinos } & 65 \%\end{array}$




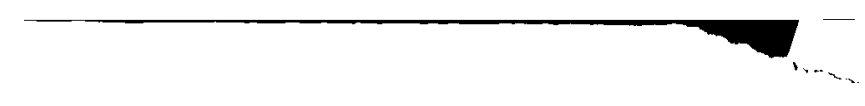

The net present value (NPV) indicates the value to the farmer now, of the change undertaken now with benefits accruing over the next 15 years (Table 4).

The Merino purchasing option involves the greatest expenditure on stock. A $10 \%$ change in gross margin results in a $13 \%$ change in NPV for the purchasing option compared with $11.5 \%$ and $12.1 \%$ changes respectively for the Romney and cross breeding options.

Grading up to Merinos is a long term breeding objective. Termination of the programme at year 5 or 10 instead of at year 15 affects the NPV (Table 5).

The internal rate of return (IRR) is an alternative way of comparing the three options (Table 6).

\section{DISCUSSION}

The economic comparisons in Table 2 indicate a consistent advantage to farming Merino wethers over a crossbred ewe flock. The doubling of the farm cash surplus $(\$ 33,100$ extra on a typical Wanganui hard hill country farm or $\$ 4,400$ allowing for extra stock capital costs) more than compensates for a few extra management problems.

These results, supported by widespread farmer experience, indicate that the Merino is much more adaptable than expected. Merinos do have special problems that usually require more or different management. We consider flystrike to be the most serious problem in many North Island environments, but challenges from internal parasites and footrot are also new to Merinos. Fleece rot and discoloration are far less common than expected.

Dependence on a single product makes commercial farming of Merinos a higher risk enterprise. The consistent historical advantage of farming Merinos over crossbreds (Table 3) shows that risk has been minimal through the $1980 \mathrm{~s}$. The fluctuating advantage of Merinos, although at times small, has remained positive even during the years of high lamb prices and subsidy support e.g. 1983184.

Successful commercial farming of Merinos in the North Island requires an important attitudinal change by the farmer. He (or she) needs to concentrate on 'wool for profit'. Many find it difficult to make that change, and simply treat Merinos as Romneys with fine wool. Size and growth rate of lambs and lambing percentages are of limited significance with Merinos, but many farmers find this difficult to accept. Because prelamb shorn Merino ewes usually look very thin, farmers often overfeed them to try to make them look like Romneys. Feed-induced bearing problems are common where farmers have recently changed to Merinos.

Once the decision to establish a Merino flock has been taken, the choice between buying or crossbreeding should be influenced by impressions of the short term versus long term future of the fine wool industry and current prices of Merinos stock. The advantage of buying-in is that current premiums can be captitalised on immediately, rather than waiting 15 years or so to reap the full reward, which cannot be guaranteed to exist that far into the future. Table 4 indicates that up to $\$ 119 /$ su extra could be justified on purchasing Merinos compared with continuing with Romneys.

Because of the high initial cost of purchasing Merinos the advantage of this option increases with the term over which the benefits are measured (Table 5). However from year 14 on (Figure 1), the breedingup option is the most profitable.

The advantage of crossbreeding to Merinos is the low initial cost and the ability to capitalise on attributes of the existing crossbred ewe flock which is suited to the farm environment. The advantage over continuing to farm crossbreds is immediate although initially small.

Because of the higher expenditure on stock the purchasing Merino option shows a lower IRR than the other two options (Table 6).

New Zealand should concentrate on high quality fine wool production. Provided the best genetic material is accessible, the North Island, with a more favourable pasture growth pattern, is probably capable of producing fine wool of higher quality than that from some of the traditional South Island areas.

Acknowledgements Te Moana Nui Development Trust for some funding assistance. Mike Toms and Allan Nimmo for stock handling.

REFERENCES

Dobbie, J.L.; Hickey, S.M.; Smart, S.H. 1985. Farming for fine wools. Ruakura Farmers Conference: 16-20.

MAFTech North Central June 1989. MAF Farm Monitoring Report, North Central Region, June 1989.

New Zealand Meat \& Wool Board Economic Service 1981-1988. The NZ Sheep \& Beef Farm Survey \& Supplement.

New Zealand Wool Board 1988. Statistical Handbook 1987-88 p. 10

New Zealand Wool Board 1988. Annual Report 1987-88. p. 10 . 